\title{
Sectoral features in the formation of food industry enterprises competitiveness: case of Ukraine
}

\author{
Nataliia Skopenko ${ }^{1}$, Halyna Kundieieva ${ }^{1}$, \\ Iryna Yevsieieva-Severyna², Olha Mykhailenko
}

\author{
1 - National University of Food Technologies, Ukraine \\ 2 - Taras Shevchenko National University of Kyiv, Ukraine
}

Keywords:

Food

Industry

Competitiveness

PESTEL analysis

Ukraine

\section{Article history:}

Received 23.01.2020

Received in revised

form 16.05.2020

Accepted 30.09.2020

\section{Corresponding} author:

Nataliia Skopenko

E-mail:

skopnata67@gmail.com

DOI: $10.24263 / 2304-$

974X-2020-9-3-17

\section{Abstract}

Introduction. The purpose of research is to determine the main factors that influence on competitiveness of Ukrainian enterprises of various food sectors and assess their impact on the formation of competitive advantages.

Materials and methods. The analysis of scientific publications allowed to determine the most effective methods: a contextual comparative analysis to identify the force of influence on the competitiveness of Ukrainian food industry enterprises and expert method assessment.

Results and discussion. The main factors that reduce the competitiveness of Ukrainian food industry enterprises are: oligopolization of markets, high level of shadow sector, outdated technical level and technologies, low level of innovation activities, raw materials shortage and underdeveloped raw material sector, dependence on imported raw materials, weak logistics infrastructure, reduction of purchasing power, political and economic instability.

The most important factors that have a positive impact on the competitiveness of food industry enterprises and the formation of competitive advantages are: affiliation of food industry enterprises to transnational corporations, innovation activities and manufacturing modernization, compliance of products with international standards, deep recycling of raw materials, production of ecological products.

Ways of developing the competitive advantages are: rapid adaptation to changes, improving the efficiency production processes, taking into account the industry specifics and peculiarities of doing business, implementation of environmental standards in manufacturing. The force of factors that influence on the competitiveness of enterprises is different due to sectoral features of functioning.

Conclusion. The proposed approach allows to predict changes in the level of competitiveness, taking into account the industry specifics of the enterprise activity and changes of external environment, including changes in a particular commodity market. 


\section{Introduction}

Enterprise competitiveness in current conditions is one of the defining characteristics of the efficiency of its economic activity and at the same time opportunities for further development.

According to Michael Porter, an American economist who is recognized as a specialist in the study of economic competition, competitiveness is the ability of a product, service, market entity to act on the market on a par with similar products, services, or competing market entities (Porter, 1990) [1]. However, selecting the price leadership strategy, differentiation or concentration, it is necessary to focus the attention on the development level of a certain enterprise, market factors, industry specifics and future growth opportunities.

Paul Krugman revived Adam Smith's idea that the size of the company is very important. He notes that often the efficiency of production directly depends on its size. As a result, goods produced at large enterprises in industrial countries, despite the much higher cost of labor, are cheaper than the same products in less developed countries (Krugman, 1996) [2]. At the same time, the majority of production plants are located in regions with cheaper labor force and other factors of production, ensuring constant control of quality indicators of finished products. Enterprise location choice in highly developed countries or in less developed countries remains a discussion issue.

C. Prahalad and G. Hamel emphasized that the competitiveness of an enterprise is based on "key competences", being a set of necessary skills. Due to them, an enterprise may gain specific benefits which translate into long-term advantage and, as a consequence, competitive position on the market (Hamel, Prahalad, 1996) [3]. However, it is advisable to consider the development of a competitive positioning and the factors influencing the competitive advantages.

Modern researchers prove that competitiveness is ensured at different levels. Thus, competitiveness can be found to describe processes of the globalising economy for companies (micro level), industrial sectors and regions (meso level) as well as for national economies (macro level). Thus, considering the pyramid model of competitiveness, it is crucial to examine all its levels in the system of competitive relations (product competitiveness - enterprise competitiveness industry competitiveness - economic competitiveness - economic leadership) (Banwet, Momaya, Shee, 2002; Siudek T, Zawojska A., 2014; Bhawsar, Chattopadhyay, 2015; Tyunyukova, Ruban, Burovtsev, 2018; Vlados, Katimertzopoulos, 2018; Vlados, Chatzinikolaou, 2020)[4 -9]. But the unresolved issue is the investigation of sectoral features of food processing enterprises and factors that form their competitiveness.

The purpose of research - to determine the main factors that justify the competitiveness of Ukrainian enterprises of various food industries at the meso level and assess their impact on the formation of competitive advantages and disadvantages.

\section{Materials and methods}

\section{Object and subject of study}

Object of study is the process of identifying the factors that influence on competitiveness of Ukrainian enterprises of various food sectors in modern market conditions.

Subject of study is a methodology and applied aspects of competitiveness of Ukrainian enterprises of various food industry sectors. 


\section{Research methods of enterprises competitiveness}

The authors proposed a methodology to assess the impact of main factors on competitiveness of Ukrainian enterprises of various food industry sectors. Conducted macroeconomic analysis allowed to determine the main factors and assess their impact on competitiveness of Ukrainian food processing enterprises and propose ways of creating and developing the competitive advantages.

For this reason, in the research paper we'll focus on the analysis and assessment of factors that determine the level of competitiveness of enterprises operating in various sectors of Ukrainian food industry.

The theoretical basis for writing of this research paper was a set of general-scientific and special methods, based on modern approaches of economic theory and management theory:

- Scientific induction and deduction - in substantiation of the essential characteristics and clarification of the concept of "competitiveness" in modern conditions (Lawson, 2005) [10];

- Historical generalization and logical - to study the evolution of the concept of competitiveness, competitive advantages and their components (Guenther, Falk, 2019) [11];

- Abstract-logic - for theoretical generalization and formation of conclusions (Patkar, 2018) [12];

- Analytic groups - for systematization and classification of factors influencing the level of competitiveness and identification of consistent patterns of their influence on the final results of economic activity (Ibrahim, 2015) [13];

- Comparison and synthesis - to reveal the direction of influence of the main factors on the development of enterprises competitiveness (Shemilt, Mugford, Vale, Marsh, Donaldson, Drummond, 2010)[14 ];

- Expert assessment - to determine the force of influence of certain factors on the competitiveness of enterprises operating in various sectors of Ukrainian food industry (Karasev, Mukanina, 2019) [15].

\section{Factors evaluation technique to justify the competitiveness of enterprises of various food industries}

Comparative analysis was applied to investigate the factors influencing the competitiveness of various food industry enterprises (Pickvance, 2001) [16]. The initial data for conducting a contextual analysis are obtained from the publications of the results of scientific research of scientists, own research, as well as empirical data on the activities of food industry enterprises in the domestic market.

Factors that have negative impact and cause the formation of competitive disadvantages (competitive weaknesses) are: oligopolization of markets, increasing level of competition with foreign companies and goods, penetration of foreign producers into the market (including plant location), import of similar goods growth, dependence on foreign raw materials, dependence on imported technology and equipment, high level of shadow sector, higher competition in the domestic market, raw materials shortage and underdeveloped domestic raw material sector, outdated technical level, using outdated technologies, insufficient inter-industry relations, shortage of working capital for raw material procurement, unable to obtain affordable credit, reduction of purchasing power 
Factors that have positive impact and cause the formation of competitive advantages (competitive strength) are: affiliation of food industry enterprises to transnational corporations, creation of different types of integrated structures, manufacturing modernization (including foreign investments), innovation activities, market growth, culture of consumption, stable financial performance and high enterprise rating activity, favourable trade conditions in international markets, product compliance with international standards, utilization of recycled and waste materials, deep recycling of raw materials, availability of highly qualified personnel, government support, stable markets for promotion of goods, production of ecological products.

\section{Research methods to evaluate the force of factors affecting competitiveness}

The necessity to determine the influence of forces of the main factors that confirm the enterprises competitiveness of various sectors of food industry has led to the use of expert assessment method. We conducted questioning with bringing of highly skilled employees from different departments of enterprises in various sectors of food industry. The survey was conducted on-line. The experts were presented with the list of factors to estimate the degree of influence of a certain factor on the competitiveness of enterprises of various sectors of food industry. It was proposed to evaluate the impact of each factor on the competitiveness of enterprises of various sectors of food industry:

- " $+++"$ - a factor has a very significant impact;

- "++" - a factor has a significant impact;

- "+" - a factor has a non significant impact;

- "-" - a factor does not affect;

- $" * "$ - the impact of the factor is not defined.

Due to the research results, main factors are determined and proved their force of influence on the enterprises competitiveness of various sectors of food industry in the strategic perspective.

\section{Results and discussion}

\section{Critical analysis of modern approaches to the theory of competitiveness}

It is crucial to consider the pyramid model of competitiveness in detail and examine all its levels (product competitiveness - enterprise competitiveness - industry competitiveness economic competitiveness - economic leadership).

Competitiveness of the goods (products) is their degree of compliance with the requirements of a target audience of consumers or the selected market for the most important characteristics: technical, economic, environmental, etc. Competitiveness of a product is a combination of its consumer properties, which ensure its success in the market in comparison with similar products of other companies (Banwet, Momaya, Shee, 2002) [4].

Competitiveness of the product is determined by the following main factors (Tyunyukova, Ruban, Burovtsev, 2018) [7]: price, quality, level of after-sales service, advertising efficiency, system marketing, timing and production technology, sales volume.

Enterprise competitiveness is the level of its competence in relation to other competing companies in accumulating and using potential of its individual components: technology, resources, management (especially strategic current planning), staff skills and knowledge, etc. for product quality improving, boosting productivity and increasing profitability. 
Enterprise competitiveness is the ability to use its strengths and concentrate its efforts in that sphere of production of goods or services where it can take an offensive position in markets (Bhawsar, Chattopadhyay, 2015; Vlados, Katimertzopoulos, 2018) [6, 8].

The main factors that determine the competitiveness of an enterprise include: company strategy, availability of materials, labor and financial resources, innovation potential, market share, management efficiency.

Industry competitiveness is reflected the enhancing firms' capabilities (through new or expanded technology, new methods) to offer better products and services, to produce products and services more efficiently, and/or to enter into new products and services (diversification) (Vlados, Chatzinikolaou, 2020) [9]. High competitiveness of enterprises which is illustrated in specific indicators provide the industry competitiveness.

Competitiveness at the national level (economic competitiveness) is based on superior productivity performance and the economy's ability to shift output to high productivity activities which in turn can generate high levels of real wages. Competitiveness is associated with rising living standards, expanding employment opportunities, and the ability of a nation to maintain its international obligations (GC, 1985) [17].

An economy is competitive if its population can enjoy high and rising standards of living and high employment on a sustainable basis (ECR, 2000) [18]. Economic leadership is the highest level of competitiveness which is characterized by an index of Gross National Happiness (to measure the collective happiness and well-being of a population) and key indicators of economic development (Verma, 2017) [19].

Review of the modern scientific research (Siudek, Zawojska, 2014; Vlados, Katimertzopoulos, 2018; Vlados, Chatzinikolaou, 2020; Balkyte, Tvaronavičiene, 2010; Momaya, 2011;) [5, 8, 9, 20, 21], made by authors, showed the enormous number of approaches to the theory of competitiveness.

From authors' point of view, enterprise competitiveness is the ability to compete and achieve high performance in certain activities accumulating and developing competitive advantages.

\section{Main factors influencing the competitiveness of enterprises}

It should be noted that we considered the level of enterprises competitiveness and industry competitiveness accordingly. The authors' research confirms that enterprise competitiveness shows the differences of one enterprise from its competitors in satisfying the customers' needs, as well as in the efficiency of production and economic activities. The concept of value chain is one of the tools for determining the enterprise competitiveness (Mostenska, Tur, 2018 ) [22]. It is also crucial to make an assessment of the competitive strength and company's competitive position. Accordingly, enterprise competitiveness is its ability to successfully compete in the market and receive economic benefits relative to competitors.

Main factors that affect the level of competitiveness of the enterprise are the following (Biukšāne, 2016; Okunevičiūtè Neverauskienè, Danilevičienè, Tvaronavičienė, 2020) [23, 24]:

Technical and technological - factors characterizing production equipment, objects of labor, technology in the workplace. This group of factors is largely decisive, because the level of mechanization and automation of production, modern technologies implementation directly affect the operational efficiency of the enterprise; 
- Organizational and management group contains factors that drive the technical and technological subsystem due to the organization of production and labor, staff selection, the introduction of a progressive wage system;

- Financial and economic factors deal with effective resource management, profitability and financial stability;

- Socio-psychological factors cover the staff of the enterprise, organizational culture, values, needs and interests of employees. It is necessary to maintain a healthy moral and psychological climate in the team, create normal working and resting conditions for the development of needs for self-actualization;

- Natural-geographical group of factors force the company to build its logistics structure, constantly improve production technology, optimize transportation schemes, reduce the energy intensity of production, etc.;

- Environmental group of factors consists of a whole complex of technical and organizational tasks due to the necessity of improving the quality of water, air, land, etc. To obtain a high competitive status;

- Industry group of factors reflects the external conditions of the business entity operating, identifying the ways of technology improvement, organization and production management at enterprises;

- Market factors include the open access to resources and new technologies, the product uniqueness, expending distribution channels and the effectiveness of sales promotion tools.

\section{Competitive advantages investigation and their classification}

From authors' point of view, the purpose of a business enterprise is to minimize costs and maximize profit for achieving its sustainable development. This proves that the management of the company should have a development strategy (business expansion, innovation, organizational change) for increasing profitability and development of competitive advantages and competitiveness as a whole.

A competitive advantage is an advantage over competitors gained by offering consumers greater value, either by means of lower prices or by providing greater benefits and service that justifies higher prices (Barney, 1995) [25]. Competitive advantage means superior performance relative to other competitors in the same industry or superior performance relative to the industry average.

From our perspective, competitive advantages are the collection of some strong prevailing characteristics of the company that clearly distinguish it from the competitors, providing further development through the production of high quality products and satisfying the growing needs of the consumers.

There is no one way to define the term "competitive advantage" and measure it. Nearly everything can be considered as competitive edge, e.g. higher profit margin, greater return on assets, valuable resource such as brand reputation or unique competence in producing jet engines. Every company must have at least one advantage to successfully compete in the market. If a company can't identify one or just doesn't possess it, competitors soon outperform it and force the business to leave the market (Thompson, Peteraf, Gamble, Strickland, Jain, 2013) [26].

The main types of competitive advantages are: (Kaleka, Morgan, 2017; Ma, 2000) [27, 28]:

Resource: availability of resource access (price and quality of raw materials, remoteness of raw material zone), long-term collaboration with producers of raw materials; 
- Technological: production capacity, availablility of modern equipment that affects the productivity and quality of finished goods, working processes optimization, patented technologies;

- Intellectual: highly skilled staff, optimal management system, innovation in tackling problems, research skills;

- Market: wide and large distribution network, exporting products, effective sales and after-sales service;

- Innovation: possibility to develop new products, implementation of new methods of production;

- Cultural: cross-cultural differences, product adaptation strategy.

Companies should develop their competitive advantages to have a high competitive position, attract new consumers and satisfy the needs of existing clients.

\section{Assessment tools used by enterprises to improve the competitiveness}

An organization can achieve an edge over its competitors in the following two ways: through external changes (a PESTEL analysis) and through internal opportunities (developing VRIO resources). PESTEL is an acronym for political, economic, social, technological, environmental and legal factors. It's a way of understanding how external forces impact your business. PEST analysis was created by Harvard professor Francis Aguilar in 1967 (Aguilar, 1967) [29]. When these factors change many opportunities arise that can be exploited by an organization to achieve superiority over its rivals. Changes in consumer demand, such as trend for eating more healthy food, can be used to gain at least temporary differentiation advantage if a company would opt to sell mainly healthy food products while competitors wouldn't. A company can also gain an upper hand over its competitors when it's capable to respond to external changes faster than other organizations. Otherwise, if a company is slow to respond to changes it may never benefit from the arising opportunities (Touati, 2013) [30].

Also, from authors' point of view to develop the enterprise competitiveness and competitive advantages it is necessary to take into account its own attributes. An enterprise can gain cost or differentiation advantage when it develops VRIO resources, unique competences or through innovative processes and products.

A company that possesses VRIO (valuable, rare, hard to imitate and organized) resources has an edge over its competitors due to superiority of such resources (Cardeal, António, 2012) [31]. If one company has gained VRIO resource, no other company can acquire it (at least temporarily). The following resources have VRIO attributes:

1. Intellectual property (patents, copyrights, trademarks)

2. Brand equity

3. Culture

4. Know-how

5. Reputation

All these attributes enhance the competitive advantages of the enterprise and facilitate its improvement and development. Many products can be identified by trademarks. Brand loyalty forms enterprise loyalty and that's crucial factor in competition (Kwan Soo Shin, Amenuvor, Basilisco, Owusu-Antwi, 2019) [32].

Brand equity is the real value for each enterprise because it provides added value (guarantee) to the clients that the product is unique (customized) and has specific (cannot be copied by competitors) characteristics. Brand image is what comes to people's mind when 
they think of specific brand. Perceived value is formed through emotion, connection and feeling (He, José Manuel Guaita-Martínez, Botella-Carrubi, 2019) [33].

Culture reflects climate and morale spirit in the company, the ability to manage their people effectively relying on trust and relationship in people management. This allows to make right decisions about which people to hire (innovative productive employees) and the best way to use their skills (Zhao, HaimengTeng, QiangWu, 2018) [34]. Know-how is an approach about knowledge of how to do something and experience in doing it. High qualified staff with innovative view to business processes enrich the company by generation of creative ideas about future development (Purc, Laguna, 2019) [35].

Reputation is perception of the company and its brands. Strong brands, perfect experience in leading business operations create a positive reputation of the enterprise. Businesses with a good reputation make greater profits. Consumers respond to the reputation is reflected by making buying decisions for or against the company (Chun, Argandoña, Choirat, Siegel, 2019) [36].

Availability of these VRIO attributes provides a sustainable competitive advantage and increases the competitiveness of enterprises in the market. In further research it is possible to apply this methodology to study the competitiveness of a particular enterprise.

\section{Study of the effectiveness of food industry development and their impact on the Ukrainian economy}

In Ukraine, as well as all over the world, complex socio-economic and political processes are taking place, which form the conditions for the development of the Ukrainian food industry, which in the global dimension is part of the world food market. In this market, Ukrainian producers traditionally have high positions.

Economic competitiveness depends on industry competitiveness and enterprises competitiveness. In 2019, mining and processing industries of Ukraine provided more than $16 \%$ of GDP according to the State Statistics Service of Ukraine. The key place among all activities in the industry belongs to the processing industry, namely the production of foodstuffs, beverages and tobacco products. In 2019, the sales volume amounted UAH 530,5 bln. or $21,4 \%$ of total industrial volume [37].

The index of industrial production analysis by types of activity showed that only the processing industry retains 3-4\% average annual growth from 2016. From 2015 to 2019, the relative stability and upward trend has been maintained only by short-term and long-term consumer goods (Table 1) [37].

The study of industrial production sales by types of activity by Ukrainian enterprises reflects positive trends in sales volumes (Table 2 and Table 3) [37]. 
Table 1

Indices of Industrial Production, by types of activity and main industrial groupings (percent over the previous period)

\begin{tabular}{|c|c|c|c|c|c|}
\hline Industry and sectors & $\begin{array}{c}\text { Code of } \\
\text { CTEA-2010 } \\
\end{array}$ & $\begin{array}{l}2016 / \\
2015\end{array}$ & $\begin{array}{l}2017 / \\
2016\end{array}$ & $\begin{array}{l}2018 / \\
2017 \\
\end{array}$ & $\begin{array}{l}2019 / \\
2018 \\
\end{array}$ \\
\hline Industry & $\mathrm{B}+\mathrm{C}+\mathrm{D}$ & 104,0 & 101,1 & 103,0 & 99,5 \\
\hline Mining and manufacturing & $\mathrm{B}+\mathrm{C}$ & 104,1 & 102,4 & 103,0 & 100,2 \\
\hline Manufacturing & $\mathrm{C}$ & 105,6 & 105,2 & 102,9 & 100,9 \\
\hline $\begin{array}{l}\text { Production of foodstuffs, beverages and } \\
\text { tobacco products }\end{array}$ & $10-12$ & 107,4 & 106,3 & 98,7 & 103,3 \\
\hline Manufacture of food products & 10 & 108,9 & 107,1 & 98,5 & 103,9 \\
\hline $\begin{array}{l}\text { Processing and preserving of meat and } \\
\text { production of meat products }\end{array}$ & 10.1 & 104,1 & 104,3 & 99,9 & 102,0 \\
\hline $\begin{array}{l}\text { Processing and preserving of fish, } \\
\text { crustaceans and molluscs }\end{array}$ & 10.2 & 128,4 & 109,2 & 114,1 & 104,0 \\
\hline $\begin{array}{l}\text { Processing and preserving of fruit and } \\
\text { vegetables }\end{array}$ & 10.3 & 106,0 & 101,6 & 109,9 & 99,4 \\
\hline $\begin{array}{l}\text { Manufacture of vegetable and animal } \\
\text { oils and fats }\end{array}$ & 10.4 & 118,4 & 117,5 & 97,9 & 113,7 \\
\hline Manufacture of dairy products & 10.5 & 99,7 & 100,8 & 101,7 & 95,1 \\
\hline $\begin{array}{l}\text { Manufacture of grain mill products, } \\
\text { starches and starch products }\end{array}$ & 10.6 & 103,1 & 98,9 & 89,2 & 104,1 \\
\hline $\begin{array}{l}\text { Manufacture of bakery and farinaceous } \\
\text { products }\end{array}$ & 10.7 & 97,6 & 98,5 & 95,0 & 94,0 \\
\hline Manufacture of other food products & 10.8 & 111,3 & 102,2 & 98,3 & 93,4 \\
\hline Manufacture of sugar & 10.81 & 133,6 & 100,9 & 89,6 & 82,8 \\
\hline $\begin{array}{l}\text { Manufacture of cocoa, chocolate and } \\
\text { sugar confectionery }\end{array}$ & 10.82 & 97,2 & 106,5 & 107,7 & 111,3 \\
\hline Processing of tea and coffee & 10.83 & 103,6 & 95,1 & 104,0 & 97,3 \\
\hline $\begin{array}{l}\text { Manufacture of condiments and } \\
\text { seasonings }\end{array}$ & 10.84 & 100,8 & 103,3 & 100,0 & 101,6 \\
\hline $\begin{array}{l}\text { Manufacture of other food products } \\
\text { n.e.c. }\end{array}$ & 10.89 & 93,8 & 102,3 & 104,9 & 64,1 \\
\hline Manufacture of beverages & 11 & 96,3 & 100,8 & 100,8 & 99,7 \\
\hline $\begin{array}{l}\text { Distilling, rectifying and blending of } \\
\text { spirits }\end{array}$ & 11.01 & 86,4 & 88,7 & 93,3 & 95,6 \\
\hline Manufacture of wine from grape & 11.02 & 103,5 & 97,2 & 88,0 & 85,6 \\
\hline $\begin{array}{l}\text { Manufacture of soft drinks; production } \\
\text { of mineral waters and other bottled } \\
\text { waters }\end{array}$ & 11.07 & 105,6 & 114,9 & 111,2 & 107,7 \\
\hline Manufacture of tobacco products & 12 & 102,2 & 95,3 & 91,4 & 87,6 \\
\hline
\end{tabular}

${ }^{1}$ data exclude the temporarily occupied territory of the Autonomous Republic of Crimea, the city of

Sevastopol and a part of temporarily occupied territories in the Donetsk and Luhansk regions

Source: authors' calculations based on data [37] 
Volume of industrial products sold by Ukrainian enterprises, by types of activity in 2016-2019 1

Mln.UAH, excluding VAT and excise

\begin{tabular}{|c|c|c|c|c|c|c|c|c|}
\hline \multirow{2}{*}{$\begin{array}{l}\text { Industry and } \\
\text { sectors }\end{array}$} & \multirow{2}{*}{\begin{tabular}{|c|} 
Code of \\
CTEA- \\
2010 \\
\end{tabular}} & \multicolumn{4}{|c|}{ Years } & \multicolumn{3}{|c|}{ Rate of change } \\
\hline & & 2016 & 2017 & 2018 & 2019 & \begin{tabular}{|l|}
$2017 /$ \\
2016
\end{tabular} & $\begin{array}{l}2018 / \\
2017\end{array}$ & \begin{tabular}{|l|}
$2019 /$ \\
2018
\end{tabular} \\
\hline Industry & $\mathrm{B}+\mathrm{C}+\mathrm{D}+\mathrm{E}$ & 1767093,3 & 2153031,3 & 2508579,5 & 2480804,2 & 121,8 & 116,5 & 98,9 \\
\hline $\begin{array}{l}\text { Mining and } \\
\text { manufacturing }\end{array}$ & $\mathrm{B}+\mathrm{C}$ & 1367751,0 & 1714038,8 & 2017721,1 & 1992299,0 & 125,3 & 117,7 & 98,7 \\
\hline Manufacturing & $\mathrm{C}$ & 1137784,9 & 1400214,0 & 1636893,0 & 1597451,8 & 123,1 & 116,9 & 97,6 \\
\hline $\begin{array}{l}\text { Production of } \\
\text { foodstuffs, beverages } \\
\text { and tobacco products }\end{array}$ & $10-12$ & 381445,1 & 451114,8 & 504332,4 & 530505,1 & 118,3 & 111,8 & 105,2 \\
\hline $\begin{array}{l}\text { Manufacture of food } \\
\text { products }\end{array}$ & 10 & 323898,9 & 380695,6 & 422730,5 & 443176,2 & 117,5 & 111,0 & 104,8 \\
\hline $\begin{array}{l}\text { Processing and } \\
\text { preserving of meat } \\
\text { and production of } \\
\text { meat products }\end{array}$ & 10.1 & 50692,4 & 62921,8 & 75160,6 & 76495,0 & 124,1 & 119,5 & 101,8 \\
\hline $\begin{array}{l}\text { Processing and } \\
\text { preserving of fish, } \\
\text { crustaceans and } \\
\text { molluscs }\end{array}$ & 10.2 & 2997,1 & 3782,2 & 4853,6 & 5681,1 & 126,2 & 128,3 & 117,0 \\
\hline $\begin{array}{l}\text { Processing and } \\
\text { preserving of fruit } \\
\text { and vegetables }\end{array}$ & 10.3 & 11267,5 & 13142,5 & 15680,6 & 18425,6 & 116,6 & 119,3 & 117,5 \\
\hline $\begin{array}{l}\text { Manufacture of } \\
\text { vegetable and animal } \\
\text { oils and fats }\end{array}$ & 10.4 & 106563,0 & 124812,0 & 132746,4 & 133365,2 & 117,1 & 106,4 & 100,5 \\
\hline $\begin{array}{l}\text { Manufacture of oils } \\
\text { and fats }\end{array}$ & 10.41 & 99154,4 & 115350,0 & 124203,9 & 127851,0 & 116,3 & 107,7 & 102,9 \\
\hline $\begin{array}{l}\text { Manufacture of dairy } \\
\text { products }\end{array}$ & 10.5 & 39972,1 & 51561,5 & 57638,6 & 60637,9 & 129,0 & 111,8 & 105,2 \\
\hline $\begin{array}{l}\text { Manufacture of grain } \\
\text { mill products, } \\
\text { starches and starch } \\
\text { products }\end{array}$ & 10.6 & 14601,3 & 16348,6 & 17402,0 & 19160,3 & 112,0 & 106,4 & 110,1 \\
\hline $\begin{array}{l}\text { Manufacture of grain } \\
\text { mill products }\end{array}$ & 10.61 & 10935,7 & 11777,1 & 12997,2 & 14132,6 & 107,7 & 110,4 & 108,7 \\
\hline $\begin{array}{l}\text { Manufacture of } \\
\text { bakery and } \\
\text { farinaceous products }\end{array}$ & 10.7 & 27307,0 & 30698,6 & 33733,7 & 37543,9 & 112,4 & 109,9 & 111,3 \\
\hline $\begin{array}{l}\text { Manufacture of } \\
\text { bread; manufacture } \\
\text { of fresh pastry goods } \\
\text { and cakes }\end{array}$ & 10.71 & 14917,2 & 17098,5 & 18840,5 & 20898,1 & 114,6 & 110,2 & 110,9 \\
\hline
\end{tabular}


Table 2 (continue)

\begin{tabular}{|c|c|c|c|c|c|c|c|c|}
\hline \multirow[t]{2}{*}{ Industry and sectors } & \multirow{2}{*}{\begin{tabular}{|c|} 
Code of \\
CTEA- \\
2010 \\
\end{tabular}} & \multicolumn{4}{|c|}{ Years } & \multicolumn{3}{|c|}{ Rate of change } \\
\hline & & 2016 & 2017 & 2018 & 2019 & $\begin{array}{l}2017 / \\
2016\end{array}$ & $\begin{array}{l}2018 / \\
2017\end{array}$ & $\begin{array}{l}2019 / \\
2018\end{array}$ \\
\hline $\begin{array}{l}\text { Manufacture of } \\
\text { macaroni, noodles, } \\
\text { couscous and similar } \\
\text { farinaceous products }\end{array}$ & 10.73 & 696,9 & 660,3 & 796,8 & 1282,7 & 94,7 & 120,7 & 161,0 \\
\hline $\begin{array}{l}\text { Manufacture of other } \\
\text { food products }\end{array}$ & 10.8 & 56632,3 & 61588,1 & 66260,7 & 68090,0 & 108,8 & 107,6 & 102,8 \\
\hline Manufacture of sugar & 10.81 & 18488,7 & 17907,5 & 15156,5 & 12232,6 & 96,9 & 84,6 & 80,7 \\
\hline $\begin{array}{l}\text { Manufacture of cocoa, } \\
\text { chocolate and sugar } \\
\text { confectionery }\end{array}$ & 10.82 & 15539,1 & 18255,6 & 21087,0 & 22472,0 & 117,5 & 115,5 & 106,6 \\
\hline $\begin{array}{l}\text { Processing of tea and } \\
\text { coffee }\end{array}$ & 10.83 & 5287,2 & 5019,7 & 5196,5 & 8550,0 & 94,9 & 103,5 & 164,5 \\
\hline $\begin{array}{l}\text { Manufacture of } \\
\text { condiments and } \\
\text { seasonings }\end{array}$ & 10.84 & 5739,9 & 7124,2 & 8562,2 & 8889,4 & 124,1 & 120,2 & 103,8 \\
\hline $\begin{array}{l}\text { Manufacture of } \\
\text { prepared meals and } \\
\text { dishes }\end{array}$ & 10.85 & 2531,4 & 3513,3 & 4560,4 & 5260,2 & 138,8 & 129,8 & 115,3 \\
\hline $\begin{array}{l}\text { Manufacture of other } \\
\text { food products n.e.c. }\end{array}$ & 10.89 & 8371,2 & 8998,0 & 10851,1 & 9737,4 & 107,5 & 120,6 & 89,7 \\
\hline $\begin{array}{l}\text { Manufacture of } \\
\text { beverages }\end{array}$ & 11 & 40856,3 & 46902,4 & 55394,0 & 61100,8 & 114,8 & 118,1 & 110,3 \\
\hline $\begin{array}{l}\text { Distilling, rectifying } \\
\text { and blending of spirits }\end{array}$ & 11.01 & 8822,9 & 9126,7 & 10433,0 & 11361,2 & 103,4 & 114,3 & 108,9 \\
\hline $\begin{array}{l}\text { Manufacture of wine } \\
\text { from grape }\end{array}$ & 11.02 & 4312,5 & 4639,0 & 4852,3 & 3518,1 & 107,6 & 104,6 & 72,5 \\
\hline Manufacture of beer & 11.05 & 14354,2 & 17369,5 & 20546,4 & 23835,7 & 121,0 & 118,3 & 116,0 \\
\hline $\begin{array}{l}\text { Manufacture of soft } \\
\text { drinks; production of } \\
\text { mineral waters and } \\
\text { other bottled waters }\end{array}$ & 11.07 & 11010,8 & 13183,6 & 16740,8 & 19164,5 & 119,7 & 127,0 & 114,5 \\
\hline $\begin{array}{l}\text { Manufacture of tobacco } \\
\text { products }\end{array}$ & 12 & 16689,9 & 23516,8 & 26207,9 & 26228,1 & 140,9 & 111,4 & 100,1 \\
\hline
\end{tabular}

${ }^{1}$ Data exclude the temporarily occupied territory of the Autonomous Republic of Crimea, the city of Sevastopol and temporarily occupied territories in the Donetsk and Luhansk regions.

Source: authors' calculations based on data [37] 
Table 3

Volume of industrial products sold outside Ukraine, by types of activity in 2016-2019', MIn.UAH, excluding VAT and excise

\begin{tabular}{|c|c|c|c|c|c|c|c|c|}
\hline \multirow{2}{*}{$\begin{array}{l}\text { Industry and } \\
\text { sectors }\end{array}$} & \multirow{2}{*}{$\begin{array}{c}\text { Code of } \\
\text { CTEA- } \\
2010\end{array}$} & \multicolumn{4}{|c|}{ Years } & \multicolumn{3}{|c|}{ Rate of change } \\
\hline & & 2016 & 2017 & 2018 & 2019 & $\begin{array}{l}2017 / \\
2016\end{array}$ & $\begin{array}{l}2018 / \\
2017\end{array}$ & $\begin{array}{l}2019 / \\
2018\end{array}$ \\
\hline Industry & $\mathrm{B}+\mathrm{C}+\mathrm{D}+\mathrm{E}$ & 466752,4 & 596313,0 & 682022,3 & 649212,1 & 127,8 & 114,4 & 95,2 \\
\hline $\begin{array}{l}\text { Mining and } \\
\text { manufacturing }\end{array}$ & $\mathrm{B}+\mathrm{C}$ & 465542,7 & 594867,8 & 679378,1 & 647175,9 & 127,8 & 114,2 & 95,3 \\
\hline Manufacturing & $\mathrm{C}$ & 408473,3 & 517745,5 & 594272,4 & 549451,3 & 126,8 & 114,8 & 92,5 \\
\hline $\begin{array}{l}\text { Production of } \\
\text { foodstuffs, beverages } \\
\text { and tobacco products }\end{array}$ & $10-12$ & 91382,9 & 122003,2 & 135342,8 & 139314,8 & 133,5 & 110,9 & 102,9 \\
\hline $\begin{array}{l}\text { Manufacture of food } \\
\text { products }\end{array}$ & 10 & 81741,8 & 110019,8 & 121572,6 & 125572,3 & 134,6 & 110,5 & 103,3 \\
\hline $\begin{array}{l}\text { Processing and } \\
\text { preserving of meat } \\
\text { and production of } \\
\text { meat products }\end{array}$ & 10.1 & 597,1 & 1127,2 & 2205,4 & 1790,7 & 188,8 & 195,7 & 81,2 \\
\hline $\begin{array}{l}\text { Processing and } \\
\text { preserving of fish, } \\
\text { crustaceans and } \\
\text { molluscs }\end{array}$ & 10.2 & 511,5 & 972,1 & 509,9 & 282,9 & 190,0 & 52,5 & 55,5 \\
\hline $\begin{array}{l}\text { Processing and } \\
\text { preserving of fruit } \\
\text { and vegetables }\end{array}$ & 10.3 & 2885,3 & 3668,7 & 3910,7 & 4191,9 & 127,2 & 106,6 & 107,2 \\
\hline $\begin{array}{l}\text { Manufacture of } \\
\text { vegetable and animal } \\
\text { oils and fats }\end{array}$ & 10.4 & 59441,8 & 79628,6 & 88918,4 & 93133,7 & 134,0 & 111,7 & 104,7 \\
\hline $\begin{array}{l}\text { Manufacture of oils } \\
\text { and fats }\end{array}$ & 10.41 & 58721,3 & 78405,9 & 87909,0 & 92601,2 & 133,5 & 112,1 & 105,3 \\
\hline $\begin{array}{l}\text { Manufacture of dairy } \\
\text { products }\end{array}$ & 10.5 & 2413,7 & 4253,9 & 4285,6 & 3841,0 & 176,2 & 100,7 & 89,6 \\
\hline $\begin{array}{l}\text { Manufacture of grain } \\
\text { mill products, } \\
\text { starches and starch } \\
\text { products }\end{array}$ & 10.6 & 2845,1 & 3681,2 & 3575,3 & 4742,4 & 129,4 & 97,1 & 132,6 \\
\hline $\begin{array}{l}\text { Manufacture of grain } \\
\text { mill products }\end{array}$ & 10.61 & 1829,0 & 2192,6 & 2099,7 & 2743,2 & 119,9 & 95,8 & 130,6 \\
\hline $\begin{array}{l}\text { Manufacture of } \\
\text { bakery and } \\
\text { farinaceous products }\end{array}$ & 10.7 & 2615,0 & 3080,5 & 4019,9 & 4207,4 & 117,8 & 130,5 & 104,7 \\
\hline $\begin{array}{l}\text { Manufacture of } \\
\text { bread; manufacture } \\
\text { of fresh pastry goods } \\
\text { and cakes }\end{array}$ & 10.71 & 358,0 & 177,0 & 152,3 & 167,1 & 49,4 & 86,0 & 109,7 \\
\hline
\end{tabular}


Table 3 (continue)

\begin{tabular}{|c|c|c|c|c|c|c|c|c|}
\hline \multirow[t]{2}{*}{ Industry and sectors } & \multirow{2}{*}{$\begin{array}{c}\text { Code } \\
\text { of CTEA- } \\
2010 \\
\end{array}$} & \multicolumn{4}{|c|}{ Years } & \multicolumn{3}{|c|}{ Rate of change } \\
\hline & & 2016 & 2017 & 2018 & 2019 & $\begin{array}{l}2017 / \\
2016\end{array}$ & $\begin{array}{l}2018 / \\
2017\end{array}$ & $\begin{array}{l}2019 / \\
2018\end{array}$ \\
\hline $\begin{array}{l}\text { Manufacture of rusks } \\
\text { and biscuits; } \\
\text { manufacture of } \\
\text { preserved pastry goods } \\
\text { and cakes }\end{array}$ & 10.72 & 2233,8 & 2890,1 & 3850,6 & 3929,0 & 129,4 & 133,2 & 102,0 \\
\hline $\begin{array}{l}\text { Manufacture of } \\
\text { macaroni, noodles, } \\
\text { couscous and similar } \\
\text { farinaceous products }\end{array}$ & 10.73 & 23,2 & 13,4 & 17,0 & 111,3 & 57,8 & 126,9 & 654,7 \\
\hline $\begin{array}{l}\text { Manufacture of other } \\
\text { food products }\end{array}$ & 10.8 & 10118,7 & 13188,3 & 13691,6 & 12988,8 & 130,3 & 103,8 & 94,9 \\
\hline Manufacture of sugar & 10.81 & 1141,5 & 2082,5 & 1691,0 & 896,6 & 182,4 & 81,2 & 53,0 \\
\hline $\begin{array}{l}\text { Manufacture of cocoa, } \\
\text { chocolate and sugar } \\
\text { confectionery }\end{array}$ & 10.82 & 5030,0 & 6003,3 & 6427,1 & 6911,5 & 119,3 & 107,1 & 107,5 \\
\hline $\begin{array}{l}\text { Processing of tea and } \\
\text { coffee }\end{array}$ & 10.83 & 137,3 & 261,4 & 270,4 & $\mathrm{~s}$ & 190,4 & 103,4 & - \\
\hline $\begin{array}{l}\text { Manufacture of } \\
\text { condiments and } \\
\text { seasonings }\end{array}$ & 10.84 & 620,1 & 776,0 & 920,0 & 977,2 & 125,1 & 118,6 & 106,2 \\
\hline $\begin{array}{l}\text { Manufacture of } \\
\text { prepared meals and } \\
\text { dishes }\end{array}$ & 10.85 & 634,4 & 802,7 & 941,8 & 970,6 & 126,5 & 117,3 & 103,1 \\
\hline $\begin{array}{l}\text { Manufacture of other } \\
\text { food products n.e.c. }\end{array}$ & 10.89 & 2549,2 & 3251,3 & 3432,5 & 2520,8 & 127,5 & 105,6 & 73,4 \\
\hline $\begin{array}{l}\text { Manufacture of } \\
\text { beverages }\end{array}$ & 11 & 2428,8 & 3184,7 & 3519,9 & 2834,6 & 131,1 & 110,5 & 80,5 \\
\hline $\begin{array}{l}\text { Distilling, rectifying } \\
\text { and blending of spirits }\end{array}$ & 11.01 & 1053,1 & 1144,8 & 1366,0 & 1334,4 & 108,7 & 119,3 & 97,7 \\
\hline $\begin{array}{l}\text { Manufacture of wine } \\
\text { from grape }\end{array}$ & 11.02 & 419,9 & 754,3 & 649,5 & 79,8 & 179,6 & 86,1 & 12,3 \\
\hline Manufacture of beer & 11.05 & 427,2 & 726,3 & 836,2 & 878,7 & 170,0 & 115,1 & 105,1 \\
\hline $\begin{array}{l}\text { Manufacture of soft } \\
\text { drinks; production of } \\
\text { mineral waters and } \\
\text { other bottled waters }\end{array}$ & 11.07 & 131,6 & 147,8 & 272,3 & 198,9 & 112,3 & 184,2 & 73,0 \\
\hline $\begin{array}{l}\text { Manufacture of } \\
\text { tobacco products }\end{array}$ & 12 & 7212,3 & 8798,7 & 10250,3 & 10907,9 & 122,0 & 116,5 & 106,4 \\
\hline
\end{tabular}

${ }^{1}$ Data exclude the temporarily occupied territory of the Autonomous Republic of Crimea, the city of Sevastopol and temporarily occupied territories in the Donetsk and Luhansk regions.

Source: authors' calculations based on data [37] 
At the same time, having unconditional success in modernizing the technology of production, improving its quality and expanding the range, Ukrainian food industry enterprises have not yet entered the trajectory of sustainable development. Ukraine is experiencing a decline in the level of food production, rising prices for raw materials, insufficient level of interaction between producers of raw materials and producers of the final product (Pimenova, Fyliuk, Pimenov, 2020; Galunets, 2019) [38, 39].

\section{Analysis of the factors influencing the competitiveness of food processing enterprises}

In the authors' opinion, investigating the factors which determine the competitive environment of Ukrainian food industry enterprises (political, economic socio-cultural, technological, legal), it is crucial to add environmental factors because they influence much on the competitiveness and increase the loyalty of consumers to the companies:

- Political factors. Functioning of enterprises depend on the laws and regulations of the country (lobbying of interests, increase or decrease in taxes, bureaucracy, corruption level, competition regulation, government stability and related changes, government involvement in trade unions and agreements, import restrictions on quality and quantity of product, etc.).

- Economic factors are connected with goods, services, and money (inflation, interest rates, exchange rates, consumers' income and purchasing power, economic growth and unemployment) (Cepel, Belas, Rozsa, Strnad, 2019) [40].

- Socio-cultural factors are the larger scale forces within cultures and societies that affect the thoughts, feelings and behaviors (cross-cultural differences, regional differences, religious beliefs, attitudes, etc.) (Bartelsman, Haltiwanger, Scarpetta, 2013) [41].

- Technological factors refer to the ways new practices and equipment can affect businesses (information communication technology, automation, e-commerce, etc.) (Andersson, Hellsmark, Sandén, 2018) [42].

- Legal factors are external factors which refer to how the law affects the way businesses operate and customers behave.

- Environmental factors. Enterprises should be eco-friendly and try to reduce consumption of resources (saving of natural resources, environmental protection, wastes utilization, alternative energy production, production of environmentally friendly food) (Ramón, 1994) [43].

The analysis of food industry competitiveness showed the heterogeneity of the situation in the industry markets. Own researches and expert assessment have shown that some factors have different force of influence on the enterprises competitiveness of different sectors of food industry. Such results should be taken into account determining the strategic priorities of enterprises development (Table 4). 
Table 4

Main factors determining the level of competitiveness of enterprises functioning in the food industry

\begin{tabular}{|c|c|c|c|c|c|c|c|c|c|c|c|c|c|}
\hline \multirow[b]{2}{*}{ Factors of competitiveness } & \multicolumn{13}{|c|}{ Sectors of food industry } \\
\hline & 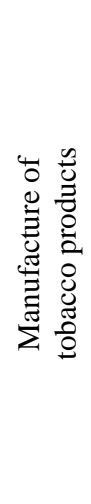 & 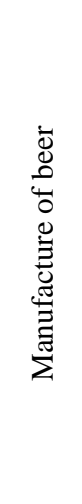 & 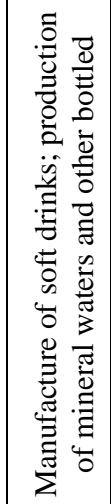 & 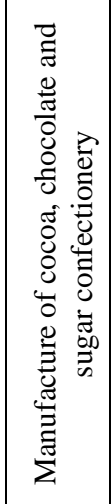 & 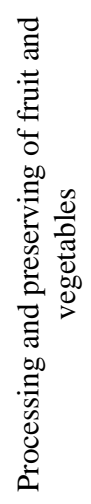 & 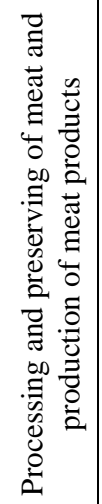 & 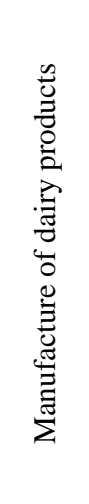 & 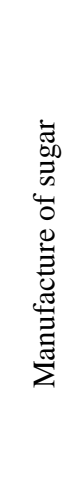 & 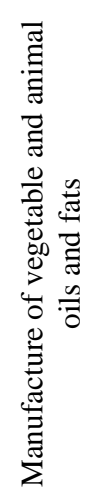 & 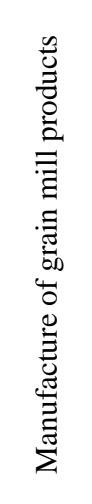 & 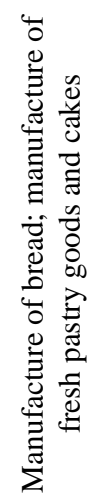 & 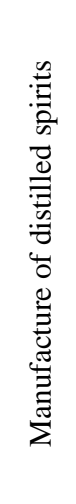 & 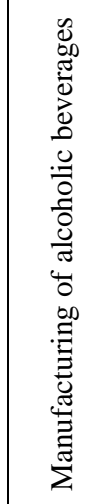 \\
\hline 1 & 2 & 3 & 4 & 5 & 6 & 7 & 8 & 9 & 10 & 11 & 12 & 13 & 14 \\
\hline \multicolumn{14}{|c|}{ Negative impact (competitive disadvantages) } \\
\hline Oligopolization of markets & +++ & +++ & +++ & +++ & + & ++ & ++ & - & +++ & - & $+/++$ & +++ & +++ \\
\hline $\begin{array}{l}\text { Increasing level of competition with foreign } \\
\text { companies and goods }\end{array}$ & +++ & +++ & ++ & +++ & +++ & $+/++$ & ++ & + & + & + & + & - & +++ \\
\hline $\begin{array}{l}\text { Penetration of foreign producers into the market } \\
\text { (including plant location) }\end{array}$ & +++ & ++ & ++ & + & + & $*$ & ++ & - & +++ & - & - & - & + \\
\hline Import of similar goods growth & +++ & +++ & + & +++ & +++ & ++ & ++ & + & + & + & + & - & $++/+++$ \\
\hline Dependence on foreign raw materials & +++ & +++ & ++ & ++ & $*$ & ++ & $+/++$ & + & - & - & + & - & - \\
\hline $\begin{array}{l}\text { Dependence on imported technology and } \\
\text { equipment }\end{array}$ & +++ & +++ & $++/+++$ & $++/+++$ & ++ & ++ & ++ & + & ++ & + & + & - & ++ \\
\hline High level of shadow sector & ++ & +++ & ++ & ++ & + & ++ & - & - & - & - & + & +++ & +++ \\
\hline Higher competition in the domestic market & +++ & +++ & $++/+++$ & +++ & ++ & ++ & +++ & $*$ & $+/++$ & $+/++$ & ++ & + & +++ \\
\hline $\begin{array}{l}\text { Raw materials shortage and underdeveloped } \\
\text { domestic raw material sector }\end{array}$ & +++ & ++ & + & ++ & ++ & +++ & +++ & ++ & - & + & + & - & + \\
\hline Outdated technical level & - & - & + & + & ++ & ++ & + & +++ & - & ++ & ++ & +++ & ++ \\
\hline
\end{tabular}




\begin{tabular}{|c|c|c|c|c|c|c|c|c|c|c|c|c|c|}
\hline 1 & 2 & 3 & 4 & 5 & 6 & 7 & 8 & 9 & 10 & 11 & 12 & 13 & 14 \\
\hline Using outdated technologies & - & + & + & $+/++$ & +++ & $+/++$ & $+/++$ & +++ & - & +++ & ++ & +++ & ++ \\
\hline Insufficient inter-industry relations & +++ & +++ & +++ & ++ & +++ & ++ & ++ & +++ & ++ & ++ & ++ & ++ & ++ \\
\hline $\begin{array}{l}\text { Shortage of working capital for raw material } \\
\text { procurement }\end{array}$ & ++ & ++ & ++ & ++ & +++ & +++ & +++ & +++ & ++ & +++ & +++ & +++ & ++ \\
\hline Unable to obtain affordable credit & + & ++ & ++ & ++ & +++ & +++ & +++ & +++ & + & +++ & +++ & +++ & ++ \\
\hline Reduction of purchasing power & ++ & ++ & +++ & +++ & ++ & +++ & +++ & + & ++ & +++ & +++ & $*$ & + \\
\hline \multicolumn{14}{|c|}{ Existing competitive advantages } \\
\hline $\begin{array}{l}\text { Affiliation of food industry enterprises to } \\
\text { transnational corporations }\end{array}$ & +++ & +++ & +++ & + & - & ++ & ++ & - & +++ & - & - & - & + \\
\hline $\begin{array}{l}\text { Creation of different types of integrated } \\
\text { structures }\end{array}$ & + & ++ & ++ & +++ & ++ & ++ & ++ & + & +++ & ++ & $+/++$ & ++ & ++ \\
\hline $\begin{array}{l}\text { Manufacturing modernization (including foreign } \\
\text { investments) }\end{array}$ & +++ & +++ & +++ & +++ & ++ & ++ & ++ & - & +++ & - & ++ & - & + \\
\hline Innovation activities & +++ & +++ & ++ & $++/+++$ & ++ & ++ & ++ & $-1+$ & +++ & $+/++$ & ++ & - & + \\
\hline Market growth & ++ & ++ & +++ & + & ++ & ++ & ++ & + & + & ++ & + & ++ & ++ \\
\hline Culture of consumption & +++ & +++ & ++ & +++ & ++ & +++ & +++ & ++ & +++ & +++ & ++ & $*$ & +++ \\
\hline $\begin{array}{l}\text { Stable financial performance and high enterprise } \\
\text { rating activity }\end{array}$ & +++ & +++ & +++ & ++ & ++ & ++ & ++ & - & +++ & $+/++$ & ++ & + & ++ \\
\hline $\begin{array}{l}\text { Favourable trade conditions in international } \\
\text { markets }\end{array}$ & +++ & $++/+++$ & ++ & $+/++$ & $*$ & + & + & + & +++ & - & + & - & $+/++$ \\
\hline Product compliance with international standards & +++ & +++ & +++ & +++ & + & ++ & ++ & + & +++ & + & ++ & ++ & +++ \\
\hline Utilization of recycled and waste materials & $*$ & + & $*$ & + & + & + & + & + & +++ & + & + & + & $*$ \\
\hline Deep recycling of raw materials & ++ & + & $*$ & + & +++ & +++ & +++ & ++ & +++ & ++ & ++ & ++ & $*$ \\
\hline Availability of highly qualified personnel & +++ & +++ & +++ & +++ & ++ & +++ & +++ & +++ & +++ & +++ & +++ & +++ & +++ \\
\hline Government support & - & - & - & - & - & - & + & - & - & ++ & ++ & ++ & - \\
\hline Stable markets for promotion of goods & +++ & ++ & ++ & ++ & ++ & ++ & ++ & ++ & ++ & ++ & ++ & +++ & +++ \\
\hline Production of ecological products & - & - & ++ & ++ & ++ & ++ & ++ & + & ++ & ++ & ++ & - & - \\
\hline
\end{tabular}

Indication: "+++" - a factor has a very significant impact;

"++" - a factor has a significant impact;

"+" - a factor has a non significant impact;

"-" - a factor does not affect;

"*" - the impact of the factor is not defined.

Source: Authors' own research 
Expert assessment and own research have proven that the specified factors can have both negative influence and cause the formation of competitive disadvantages (competitive weaknesses) and positive influence and prove the formation of competitive advantages (competitive strength).

On the basis of expert assessment it has been shown that the force of the influence of each factor on the enterprises competitiveness of various industries is different. According to the table 4, one factor may have a very significant impact or not affected on the formation of enterprises competitiveness in certain industries. So the dependence on foreign raw materials has a very strong influence on manufacture of tobacco products and beer and has a moderate influence on manufacture of soft drinks and cocoa, chocolate and sugar confectionery, while the enterprises of manufacturing the distilled spirits and alcoholic beverages are used Ukrainian raw materials. Among competitive advantages, we should mention that production of ecological products is the advantage of enterprises which produce soft drinks; mineral waters and other bottled waters, confectionery, canned fruits and vegetables, meat products, sugar, sunflower oil, flour and cereals, but for instance tobacco and alcohol products do not have such advantage. However, general environmental friendliness of production is an important competitive advantage for all enterprises of food industry.

The research has proved that different factors can both increase and decrease the level of competitiveness of Ukrainian enterprises in food markets.

Conducted macro analysis allowed to determine the main factors that prove the competitiveness of enterprises in various food industries.

Analyzing the changeable market environment, the main aspects which should be emphasized by modern mangers for future development of food industry enterprises are following:

- Higher efficiency (enterprises need to be efficient and try to cut costs in order to survive);

- Increasing quality of processes and products;

- Better material and ingredients usage and meeting higher standards (companies in food industry should always stick to the standards of health which means they should be care about ingredients which products consist with; also enterprises usually compete with the quality and nutritional value of the goods);

- Lower prices according to purchasing power;

- Greater output (companies will produce more goods and range of product to satisfy customers' needs and allow them to choose products);

- Rivalry among the companies and opportunities of the clients to switch on the substitute products (complication, sometimes impossibility to forecast and prognostication of competitors' actions);

- Seasonality and the culture of products consumption.

\section{Conclusions}

Thus, growth of competition on the market causes the necessity of improving the enterprise activity. Considering the possible ways of development of competitive advantages, it is necessary:

- To review the organizational structure in order to ensure better coordination of different departments;

- To understand and implement the procedures and rules in practical activity of the enterprise to achieve rationalization of processes; 
- To ensure the possibility of rapid adaptation of the enterprise to changes in the external environment (innovative products, new customers' needs, market expansion, improvement of logistics processes, etc.);

- To implement the best management practices of other companies, taking into account the industry specifics and peculiarities of doing business (resource-saving technologies, improving the organization processes, methods of personnel management);

- To introduce the modern systems of product quality management, improve the technical control methods, implement the modern forms and methods of production.

\section{References}

1. Porter M. (1990), The Competitive Advantage of Nations, Free Press, New York, DOI: $10.1007 / 978-1-349-11336-1$

2. Krugman P. (1996), Making Sense of the Competitiveness Debate, Oxford Review of Economic Policy, 12(3), pp. 17-25.

3. Hamel G., Prahalad C. K. (1996), Competing for the Future, Harvard Business Review Press.

4. Banwet D. K., Momaya K., Shee H. K. (2002), Competitiveness: Perceptions, reflections and directions, IIMB Management Review, 14(3), pp. 105-116.

5. Siudek T, Zawojska A. (2014), Competitiveness in the economic concepts, theories and empirical research, Acta scientiarum polonorum, 13(1), pp. 91-108.

6. Bhawsar P., Chattopadhyay U. (2015), Competitiveness: Review, reflections and directions, Global Business Review, 16(4), pp. 665-679.

7. Tyunyukova E., Ruban V., Burovtsev V. (2018), Modern approaches to product competitiveness evaluation for companies of various industries, MATEC Web of Conferences 216, DOI: 10.1051/matecconf/201821602016

8. Vlados C. M., Katimertzopoulos F. (2018), Assessing Meso and MicroCompetitiveness Boosting Policies, in Stra.Tech.Man Terms, International Journal of Business and Social Research, 08(09), pp. 01-15, DOI: 10.18533/ijbsr.v8i9.1127

9. Vlados C., Chatzinikolaou D. (2020), Macro, Meso, and Micro Policies for Strengthening Entrepreneurship: Towards an Integrated Competitiveness Policy, Journal of Business \& Economic Policy, 7(1), pp. 1-12, Available at: https://ssrn.com/abstract=3563453

10. Lawson A. E. (2005), What is the role of induction and deduction in reasoning and scientific inquiry? Journal of Research in Science Teaching, 42(6), pp. 716-740, DOI: 10.1002/tea.20067

11. Guenther J., Falk I. (2019), Generalising from Qualitative Research (GQR): A New Old Approach, The Qualitative Report 2019, 24(5), pp. 1012-1033, Available at: https://nsuworks.nova.edu/tqr/vol24/iss5/6

12. Patkar V. (2018), Research Methodology: Logic, Methods and Cases, Vikalpa: The Journal for decision maker, 43(3), pp. 175-177, Available at: DOI: $10.1177 / 0256090918796953$

13. Ibrahim M. (2015), The art of Data Analysis, Available at: https://www.researchgate.net/publication/283269432

14. Shemilt I., Mugford M., Vale L., Marsh K., Donaldson C., Drummond M. (2010), Research Synthesis Methods, Europe PMC, 1(2), pp. 126-135, Available at: DOI: $10.1002 / j r s m .14$ 
15. Karasev O.I., Mukanina E.I. (2019), Expert assessment method in foresight studies, Statistics and Economics, 16(4), pp. 4-13, Available at: DOI: 10.21686/2500-39252019-4-4-13

16. Pickvance C. (2001), Four Varieties of Comparative Analysis, Journal of Housing and the Built Environment, 16(1), pp. 7-28, Available at: DOI: 10.1023/A:1011533211521

17. (1985), Global Competition: The New Reality - Report of the President's Commission on Industrial Competitiveness), Publisher: U.S. Government Printing Office.

18. (2000), European competitiveness report - 2000, Luxembourg: Office for Official Publications of the European Communities.

19. Verma R. (2017), Gross National Happiness: Meaning, Measure and Degrowth in a Living Development Alternative, Journal of Political Ecology, 24(1), pp. 476-490, Available at: http://DOI: 10.2458/v24i1.20885

20. Balkyte A., Tvaronavičiene M. (2010), Perception of competitiveness in the context of sustainable development: Facets of "sustainable competitiveness", Journal of Business Economics and Management, 11(2), pp. 341-365, Available at: http://DOI: 10.3846/jbem.2010.17

21. Momaya K. (2011), Cooperation for competitiveness of emerging countries: Learning from a case of nanotechnology, Competitiveness Review: An International Business Journal, 21(2), pp. 152-170, Available at: DOI: $10.1108 / 10595421111117443$

22. Mostenska T. L., Tur O. V. (2018), Rol lantsiuha stvorennia tsinnosti u zabezpechenni konkurentospromozhnosti pidpryiemstv, Visnyk Cherkaskoho universytetu: Ekonomichni nauky, 4., pp. 75-84.

23. Biukšāne I. (2016), Model of the Factors Influencing Competitiveness of the Latvian Fisheries Sector Cluster, Economics and Business, 28, pp. 76-82, Available at: DOI 10.1515/eb-2016-0011

24. Okunevičiūtė Neverauskienė L., Danilevičienė I.,Tvaronavičienė M. (2020), Assessment of the factors influencing competitiveness fostering the country's sustainability, Journal Economic Research Ekonomska Istraživanja, 33 (1), pp. 1909-1924, Available at: DOI: 10.1080/1331677x.2020.1763821

25. Barney B. J. (1995), Looking inside for Comp. Adv, Academy of Management Executive, 9(4), pp. 49-61, Available at: http://www.jstor.org/stable/4165288?seq=1

26. Thompson A., Peteraf M., Gamble J., Strickland A. J., Jain A. K. (2013). Crafting \& executing strategy: The quest for competitive advantage: Concepts and cases, McGraw-Hill Education, New Delhi

27. Kaleka A., Morgan N. (2017), Which Competitive Advantage(s)? Competitive Advantage - Market Performance Relationships in International Markets, Journal of International Marketing, 25(4), Available at: DOI: 10.1509/jim.16.0058

28. Ma H. (2000), Competitive advantage and firm performance, Competitiveness Review, 10(2), pp. 15-32, Available at: DOI: 10.1108/eb046396

29. Aguilar F. J. (1967), Scanning the business environment., Macmillan, New York

30. Touati J. (2013), The PESTEL Environment and Its Impact on the Value Created, International journal of management \& information technology, 6(2), pp. 805-816, DOI: $10.24297 /$ ijmit.v6i2.738

31. Cardeal N., António N. (2012), Valuable, rare, inimitable resources and organization (VRIO) resources or valuable, rare, inimitable resources (VRI) capabilities: What leads to competitive advantage?, South African Journal of 
Business Management, 6(37), pp. 10159-10170, Available at: https:// DOI: 10.5897/AJBM12.295

32. Kwan Soo Shin S., Amenuvor F. E., Basilisco R., Owusu-Antwi K. (2019), Brand Trust and Brand Loyalty: A Moderation and Mediation Perspective, Current Journal of Applied Science and Technology, 38(4), pp. 1-17, Available at: https:// DOI: $10.9734 / C J A S T / 2019 / v 38 i 430376$

33. He Q., José Manuel Guaita-Martínez J. M., Botella-Carrubi D. (2019), How brand equity affects firm productivity: The role of $\mathrm{R} \& \mathrm{D}$ and human capital, Journal Economic Research Ekonomska Istraživanja, pp. 2976-2992, Available at: https:// DOI: 10.1080/1331677X.2019.1686045

34. Zhao H., Haimeng Teng H., Qiang Wu Q. (2018), The effect of corporate culture on firm performance: Evidence from China, China Journal of Accounting Research, 11(1), pp. 1-19, Available at: DOI: 10.1016/j.cjar.2018.01.003

35. Purc E, Laguna M. (2019), Personal Values and Innovative Behavior of Employees, Frontiers in Psychology, Available at: https:// doi: 10.3389/fpsyg.2019.00865

36. Chun R., Argandoña A., Choirat C., Siegel D. S. (2019), Corporate Reputation: Being Good and Looking Good , Business \& Society, Available at: https:// DOI: $10.1177 / 0007650319826520$

37. (2020), State Statistics Service of Ukraine, Available at: http://www.ukrstat.gov.ua/

38. Pimenova O., Fyliuk H., Pimenov S. (2020), Model of assessment of competitiveness and sustainable development of Ukrainian agricultural enterprises, Management Theory and Studies for Rural Business and Infrastructure Development, 42 (3), pp. 330-338, Available at: DOI: 10.15544/mts.2020.33

39. Galunets N. (2019). Place of the Ukrainian agricultural exports on the world food market, Agricultural and Resource Economics: International Scientific E-Journal, 5(4), pp. 79-94, Available at: https://are-journal.com/index.php/are/article/view/269

40. Cepel M., Belas J., Rozsa Z., Strnad Z. (2019), Selected economic factors of the quality of business environment, Journal of International Studies, 12(2), pp. 228 240, Available at: https://DOI:10.14254/2071-8330.2019/12-2/14

41. Bartelsman E., Haltiwanger J., Scarpetta S. (2013), Cross-country differences in productivity: The role of allocation and selection, American Economic Review, 103(1), pp. 305-334, Available at: https://DOI. 10.1257/aer.103.1.305

42. Andersson J., Hellsmark H., Sandén B. A. (2018), Shaping factors in the emergence of technological innovations: The case of tidal kite technology, Technological Forecasting and Social Change, 132(C), pp. 191-208, Available at: DOI: 10.1016/j.techfore.2018.01.034

43. Ramón L. (1994), The Environment as a Factor of Production: The Effects of Economic Growth and Trade Liberalization, Journal of Environmental Economics and Management, pp. 163-184, Available at: DOI: 10.1006/jeem.1994.1032 